\title{
Population counts and potential impact of two successful invaders in a town of Northern Italy: the case of ring-necked parakeet and Alexandrine parakeet in Reggio Emilia
}

\author{
Andrea Viviano ${ }^{1}$, Emiliano Mori ${ }^{2 *}$
}

\begin{abstract}
In our paper, we reported the presence of two alien species in the city of Reggio Emilia, the ring-necked parakeet Psittacula krameri and the Alexandrine parakeet Psittacula eupatria. The ringnecked parakeet is widespread throughout Europe with many colonies known also for Italy, whereas the Alexandrine parakeet has been only recorded in the last 10-15 years and, apart from few individuals in Rome, the breeding population in Reggio Emilia is the largest one in Italy. We carried winter counts following standard methods through counts at roosts. About 78-80 ring-necked and at least 16 Alexandrine parakeets were counted, including also some hybrids between the two species, which were morphologically identified by the pale colour of the shoulders. Although no claims of crop damage are yet reported, parakeets of both species may feed on ripe and unripe persimmons in private gardens, reducing the total fruit production by up to $75-80 \%$. Furthermore, four Savi's pipistrelle Hypsugo savii have been killed by ring-necked parakeets in early spring 2019 . Therefore, the current trend of these species in the town could lead to further expansion into suburban farmland areas, increasing potential conflicts with human activities.
\end{abstract}

Key words: biological invasions, population counts, Psittaciformes, Psittacula eupatria, Psittacula krameri.

Riassunto - Conteggi di popolazione e impatto potenziale di due invasori di successo in una città del Nord Italia: il caso del parrocchetto dal collare e del parrocchetto di Alessandro a Reggio Emilia.

In questo lavoro, abbiamo riportato la presenza di due specie aliene nella città di Reggio Emilia, il parrocchetto dal collare Psittacula krameri e il parrocchetto di Alessandro Psittacula eupatria. Il parrocchetto dal collare è una specie alloctona diffusa in tutta Europa e molte colonie sono presenti dagli anni ' 80 anche in Italia. Il parrocchetto di Alessan-

\footnotetext{
' Dipartimento di Scienze Agrarie, Alimentari e Agro-ambientali, Produzioni Agroalimentari e Gestione degli Agroecosistemi, Università degli Studi di Pisa, Via del Borghetto 80, 56124 Pisa, Italia.

E-mail: a.viviano@studenti.unipi.it ORCID: 0000-0002-2970-3389

${ }^{2}$ Consiglio Nazionale delle Ricerche, Istituto di Ricerca sugli Ecosistemi Terrestri, Via Madonna del Piano 10, 50019, Sesto Fiorentino (Firenze), Italia.

ORCID: 0000-0001-8108-7950

* Corresponding author: emiliano.mori@cnr.it

(C) 2021 Andrea Viviano, Emiliano Mori

Received for publication: 2 March 2021

Accepted for publication: 14 April 2021

Online publication: 21 April 2021
}

dro è invece stato registrato solo negli ultimi 10-15 anni in Europa e la popolazione riproduttiva di Reggio Emilia rappresenta la più cospicua e più antica in Italia. Abbiamo effettuato stime di popolazione durante i mesi invernali seguendo metodi standard, attraverso conteggi ai posatoi. Sono stati contati circa 78-80 parrocchetti dal collare e almeno 16 parrocchetti di Alessandro. Sono stati rilevati anche alcuni ibridi tra le due specie. Sebbene nessuna lamentela di danni alle colture sia stata effettuata, i parrocchetti di entrambe le specie possono nutrirsi di cachi maturi e acerbi, riducendo la produzione totale di frutta fino al $75-80 \%$ in giardini e orti privati. Inoltre, quattro pipistrelli del Savi Hypsugo savii sono stati uccisi da parrocchetti dal collare all'inizio della primavera 2019. Pertanto, l'attuale trend di popolazione di queste specie in città potrebbe portare a un'ulteriore espansione di questi parrocchetti nelle aree agricole situate in periferia, aumentando potenziali conflitti con le attività umane.

Parole chiave: conteggi di popolazione, invasioni biologiche, Psittaciformes, Psittacula eupatria, Psittacula krameri.

\section{INTRODUCTION}

A multitude of published studies report that biological invasions are, after habitat loss and fragmentation, the leading cause of the current global biodiversity crisis (Mack et al., 2000; Bax et al., 2003; Clavero et al., 2009; Pyšek et al., 2020). In detail, a species is defined as invasive if, once introduced outside its native range, it occupies the habitat of native species, altering the structure and the function of native ecosystems (cf. Colautti \& McIsaac, 2004). A species must pass through three processes to become invasive: introduction (i.e. release outside confined environments), establishment (i.e. reproduction and self-sustainment of the population) and spread (Lockwood et al., 2009). These considerations emphasize the crucial role of a constant and updated monitoring of the distribution and population abundance of invasive species, to better control their spread and identify areas of concern. Accordingly, introduced species may affect local ecosystems and native species by means of direct and indirect competition, predation, disease/parasite transmission, hybridisation and environmental alterations (Pyšek et al., 2020). Population monitoring and assessment of population abundance are in turn necessary to design management plans to minimize impacts on native biodiversity and environments (Genovesi \& Shine, 2004). Urban areas seem to be particularly suitable to the establishment of most alien species populations (especially birds), by showing higher mean temperatures with respect 
to natural environments, as well as because of food provisioning by humans which may help overcome critical times, such as winter and early spring (e.g. Dean, 2000; Sol et al., 2012; Seress \& Liker, 2015). In particular, the urban heat-island effect can allow alien species of tropical origins to cope with temperate winters (Le Louarn et $a l ., 2017)$. Furthermore, apart from food provided by humans (cf. Clergeau \& Vergnes, 2011; Le Louarn et al., 2016), natural food sources and roosting/nesting sites are also constant, predictable and homogeneously distributed in urban areas, because of the great number of native and ornamental exotic trees providing shelter, fruits and seeds almost throughout the year (Dodaro \& Battisti, 2014; Borray-Escalante et al., 2020). Urban areas ease invasive species by hosting less predators than natural areas and their native ranges (Mori et al., 2019; Mori \& Menchetti, 2021). In addition, some species are considered valid indicators of invasion success (Duncan et al., 2003). Smalland medium-sized, as well as widely distributed (in native ranges) species are the most apt at establishing non-native populations, because they are (i) more traded than others, (ii) commonly sold at relatively low prices, (iii) highly synanthropic and (iv) well adapted to thrive in a variety of environmental conditions and habitat types, including urban areas (e.g. Duncan et al., 2003; Kark et al., 2007; Møller, 2009; Evans et al., 2011).

Amongst introduced birds, the ring-necked parakeet Psittacula krameri (hereafter, RNP) is a species native to sub-Saharan Africa and the Indian Subcontinent, which has been widely introduced throughout the world (Menchetti \& Mori, 2014). In Europe, about 150 breeding populations of this species, mostly dramatically increasing, have been established in about 40 countries, with over 85,000 individuals, mostly occurring in urban areas (Pârâu et al., 2016; Chessa, 2020). Several ecological effects triggered by this species has been documented in Europe, ranging from competition with native hole-nesting birds and bats to crop damages and disease/parasite transmission (Mentil et al., 2018; White et al., 2019; Mori \& Menchetti, 2021). Mostly, introduced RNPs are responsible for displacing (and sometimes killing) hibernating bats when RNPs access cavities for nesting. This has been observed in Spain for the greater noctule bat Nyctalus lasiopterus (body length $=11 \mathrm{~cm}$ ) and the meridional serotine Eptesicus isabellinus (body length $=7 \mathrm{~cm}$ ), as well as in the Netherlands for the common noctule bat Nyctalus noctula (body length $=7$ $\mathrm{cm}$ ) and in Italy for the lesser noctule bat Nyctalus leisleri (body length $=6 \mathrm{~cm}$ ) (Haarsma \& Van der Graaf C, 2013; Menchetti et al., 2014; Hernández-Brito et al., 2018). Bats are injured (mostly on the wings) and killed when RNPs enter their cavities and fail at expelling them alive (Hernández-Brito et al., 2018). Furthermore, despite being a generally appreciated species (Crowley et al., 2019; Luna et al., 2019), public tolerance towards the RNP declines significantly with the increase of populations, suggesting also the involvement of this parrot in causing noise pollution (Mori et al., 2020). A similar species, the Alexandrine parakeet Psittacula eupatria (hereafter, AP) is native to India and it has a larger body-size with respect to the RNP (Souray et al., 2018). This species has been poorly recorded as an alien species, with a low number of alien popu- lations (e.g. Khaleghizadeh \& Sehhatisabet, 2006; Ancillotto et al., 2015; Postigo, 2016; Şahın \& Arslangündoğdu, 2019; Abed et al., 2020). Ancillotto et al. (2015) reported that the presence of established RNP populations might help the establishment of APs. Accordingly, several populations of alien AP successfully settled reproductive populations where RNPs already occurred. RNPs are about 30\% smaller than APs. Apart from that, these parrot species externally resemble one-another, being predominantly green with red beaks (Juniper \& Parr, 1998; Fig. 1).

Adult males of both species show a black stripe across the lower cheeks and a rose coloured band on the nape (Juniper \& Parr, 1998). Moreover, a red patch on the shoulders is present in APs (Juniper \& Parr, 1998). Hybridisation between RNP and APs is known to occur, being more frequent in introduced than in native range, with hybrids discernible thanks to distinct morphological features (i.e. yellow to orange shoulders: Krause, 2004; Postigo, 2016). Increasing evidence of impacts by introduced parakeets (Menchetti \& Mori, 2014; Hernández-Brito et al., 2018; White et al., 2019) highlights the importance of having constant updates on population increases as well as on new established populations. Both the RNP and the AP are known to occur with reproductive populations in Reggio Emilia (Northern Italy), but no data on these populations are available in the scientific literature (Ancillotto et al., 2015; Pârâu et al., 2016).

Therefore, the aim of this study has been to evaluate the status of the RNP and AP populations currently occurring in the Reggio Emilia urban area. The population size was estimated through counts at roosts. We also reported the impact by the RNP (in flocks with hybrids with AP) on persimmons, and four killing events towards Savi's pipistrelle Hypsugo savii (body length $=4-5 \mathrm{~cm}$ ).

\section{MATERIALS AND METHODS}

We conducted our fieldwork in cold months (November-December 2020), by visiting all green areas in Reggio Emilia to find suitable areas to observe parakeets. Eleven areas were visited, including urban parks, public and private flower/vegetable gardens and the green areas surrounding public buildings, including lanes with vegetation suitable for roosting. Because the RNP usually congregates at roosts, we followed the flocks at sunset to identify the roosting areas and to count individuals. When roosts were located, we employed the roost count method described by Casagrande \& Beissinger (1997) and Luna et al. (2016) and took systematic counts of all birds. Each count started $30 \mathrm{~min}$ before sunset from vantage points including all the roost area (Luna et al., 2016). We considered all the flying parakeets settled at roosts by recording them minute by minute. Parakeets were counted individually. Counts were compared with previous counts of these species in Reggio Emilia carried out after the European RNP Assessment by members of the ParrotNet project and with data stored for the European databank of parakeet distribution in this town, which includes also data from open access citizen-science platforms (cf. European RNP Assessment: cf. Pârâu et al., 2016; iNaturalist.org: Chessa, 2020).

Consumption of persimmons Diospyros kaki Thunb. 


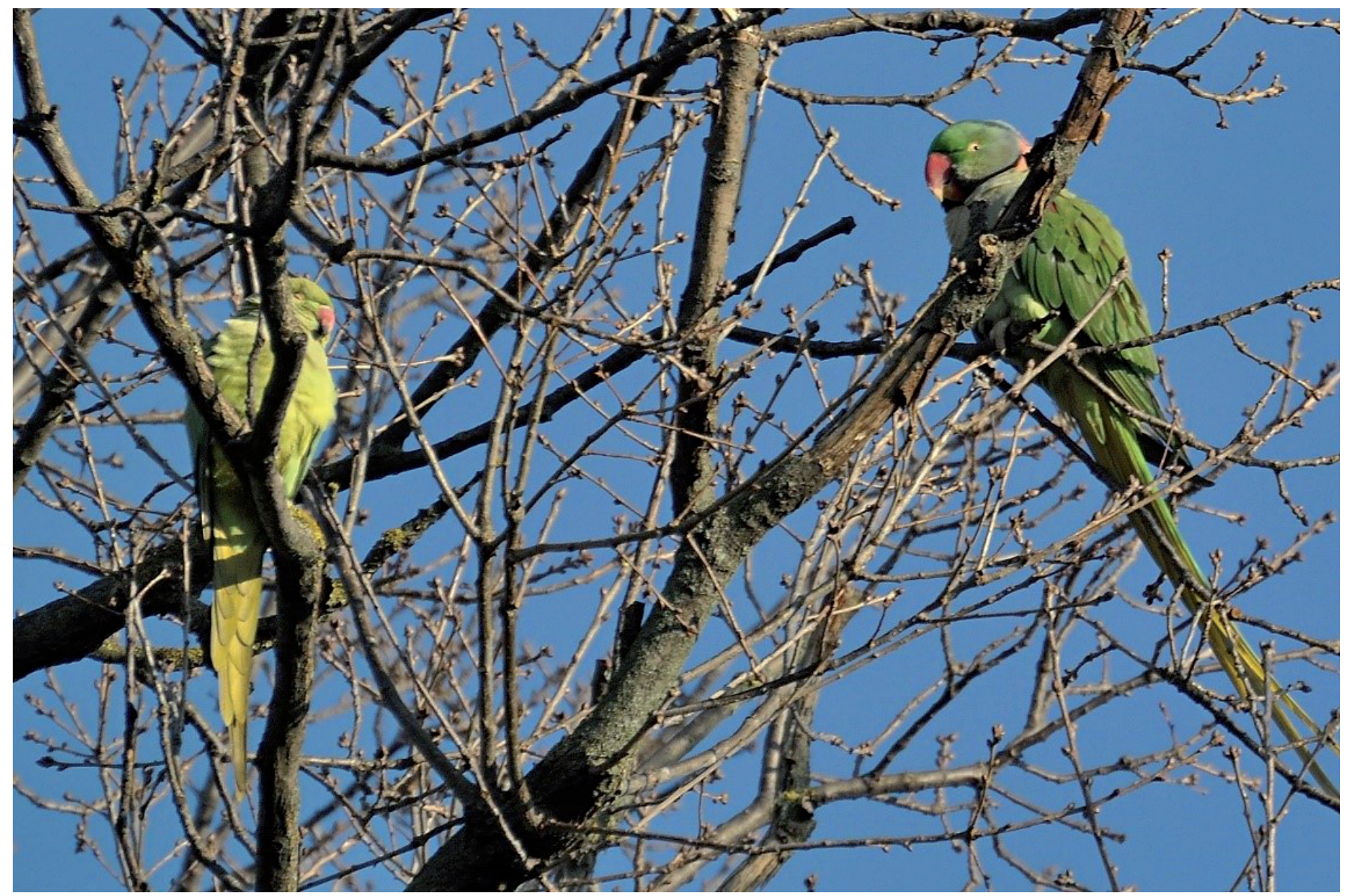

Fig. 1 - Male individuals of ring-necked parakeet (left) and Alexandrine parakeet (right) in Reggio Emilia. / Individui di sesso maschile di parrocchetto dal collare (sinistra) e parrocchetto di Alessandro (destra) a Reggio Emilia. (Photo: / Foto: S. Manfredini).

(percentage of consumed fruits on the total per tree) was recorded in September 2019 and September 2020 at the same 16 persimmon trees distributed throughout urban green areas. Even if the diet of RNP and AP includes a wide range of vegetal items, we chose persimmons, largesized orange fruits persisting on bare branches in fall, as being easier to be monitored with respect to other cultivated species. However, it would be important to quantify the total damage to crops and orchards by introduced parrots.

We reported the percentage of lost fruits in both years. We also reported the detection of killing events by RNPs against four Savi's pipistrelle displaced from roosting sites, directly observed near Parco della Mirandola in early spring 2019.

\section{RESULTS}

The presence of the RNP in Reggio Emilia dates back to 2008 , when the first individuals were observed. Currently, the population includes about 78-80 individuals, mostly roosting in urban parks in the city centre (Fig. 2). AP records in the same area occurred since 2011, with the first two observed individuals. Currently the local population (including also several hybrids with RNP) counts for about 16 individuals, mostly roosting in urban parks in the city western outskirts (Fig. 2).

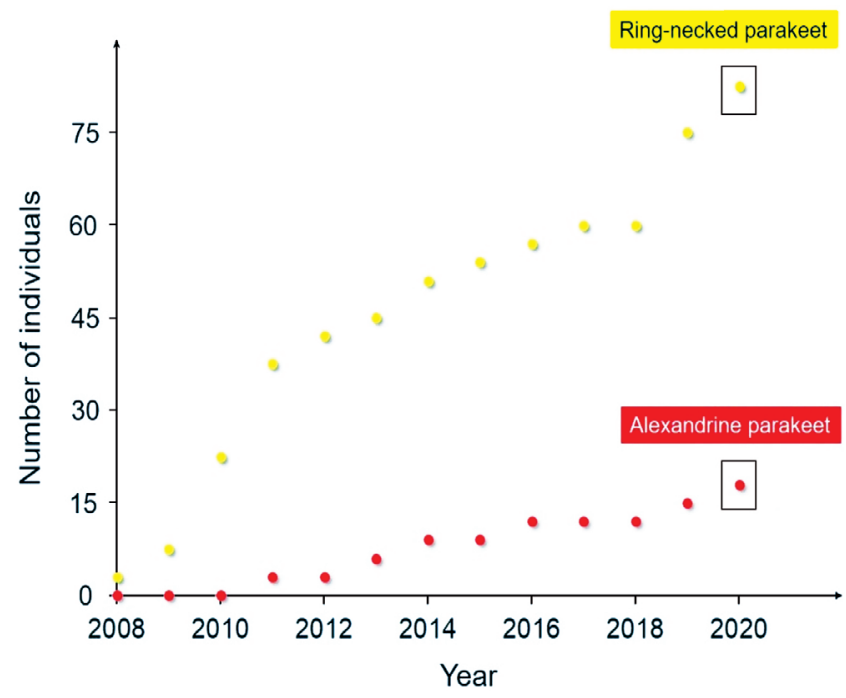

Fig. 2 - Population counts at night roosts showing the growing trends of both RNPs and APs in Reggio Emilia. Counts recorded during our 2019-2020 survey are shown in a blue rectangle. The 2008-2018 counts were obtained from the literature and citizen-science web platforms (Chessa, 2020). / Conteggi di parrocchetti ai dormitori notturni, con tendenze crescenti sia di parrocchetto dal collare sia di parrocchetto di Alessandro a Reggio Emilia. I conteggi del 2019-2020 sono riportate nel rettangolo blu. I conteggi 2008-2018 sono stati ottenuti da letteratura e da piattaforme web di citizen-science (Chessa, 2020). 
The mean percentage of consumed persimmon per tree $( \pm \mathrm{SD})$ by RNPs, APs and $\mathrm{AP} \times \mathrm{RNP}$ hybrids on the 16 monitored plants was $48.43 \pm 20.87$ in $2019,58.13 \pm$ 23.94 in 2020 (Fig. 3).

In early spring 2019, four individuals of Savi's pipistrelle were killed and partially consumed by RNPs (Fig. 4). In one case, parakeets were seen while attacking and killing a bat. At close examination, the prey showed signs of consumption on the wing patagium. The remaining three individuals were found dead on the ground below the parakeets' nests and, although not seen while under attack by RNPs, they showed feeding traces similar to those found on the first individual.

\section{DISCUSSION}

Our research investigated the growing trends of two alien species, the RNP and the AP, present in the town of Reggio Emilia (Northern Italy) and the consequent growing impact of these parakeets on persimmon cultures. These populations count for near 100 individuals, with about 80 RNPs and 16 APs. Even if we are aware that these numbers may represent underestimations, we decided to exclude from the counts at roosts the individuals seen flying among the branches to limit the potential for double counts (Luna et al., 2016).

Despite being present in Reggio Emilia since at least ten years, these populations have not been considered in previous population assessment for these species (Ancillotto et al., 2015; Pârâu et al., 2016). After Pârâu et al. (2016), a European databank on alien parrot populations has been created, together with a growing interest on parakeet distribution and impacts following the output of the COST Action named "ParrotNet" (cf. Chessa, 2020). More recently, a project on iNaturalist on alien parrots (https://www.inaturalist.org/projects/alien-parrots-observatory) has been developed. Since 2016, several new RNPs populations have been described and reported, but most of them count for less than 10-20 individuals (e.g.

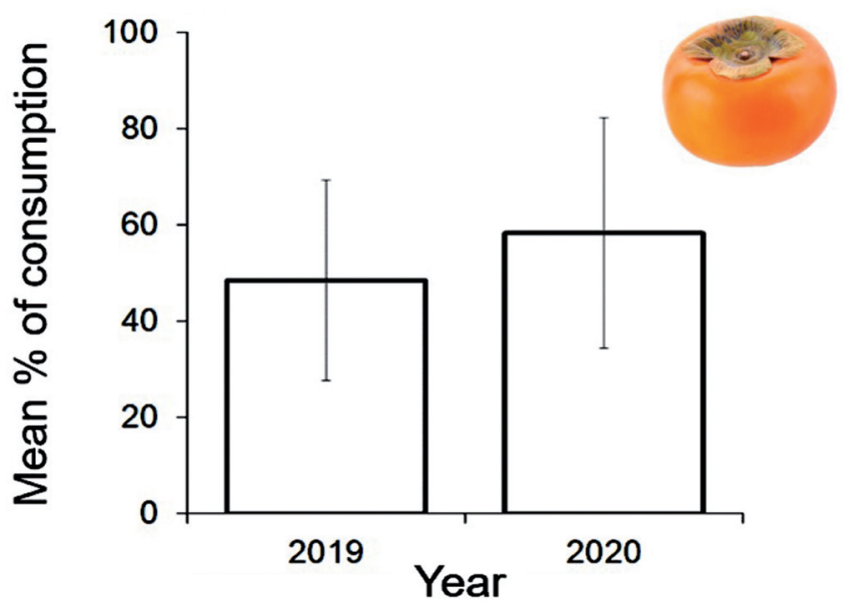

Fig. 3 - Mean consumption (and standard deviations) of persimmons by RNPs, APs and AP $\times$ RNP hybrids in 2019 and 2020. / Consumo medio percentuale (e deviazione standard) di cachi per pianta da parte di parrocchetti dal collare, parrocchetti di Alessandro e ibridi nel 2019 e nel 2020. those in Forte dei Marmi and in Savona). Conversely the population of RNP in Reggio Emilia is quite numerous, and may have derived from larger populations occurring in the surroundings. In Bologna (about $60 \mathrm{~km}$ distant from Reggio Emilia, as the crow flies), a population of over 800 individuals of RNP established since the end of the 1990s and it seems to be expanding (Pârâu et al., 2016). We cannot rule out that the Reggio Emilia and Ferrara populations (the last with a few recent breeding records) originate from that in Bologna, and it is also possible that further population increases may bring RNP to invade other urban centres in the surroundings of Reggio Emilia.

The population of AP in Reggio Emilia is the largest in Italy, with a second one in Rome counting for 4-6 individuals and hybrids with RNP (Ancillotto et al., 2015; Angelici \& Fiorillo, 2015). The settlement of AP in Reggio Emilia has occurred 3 years after the first sightings of RNP in the same town. This provides support to the hypothesis that previously established RNPs trigger interspecific facilitation that may help niche expansion and invasion success of the congeneric AP (Ancillotto et al., 2015). Furthermore, interspecific flocks often including hybrid individuals (identified according to the colour of
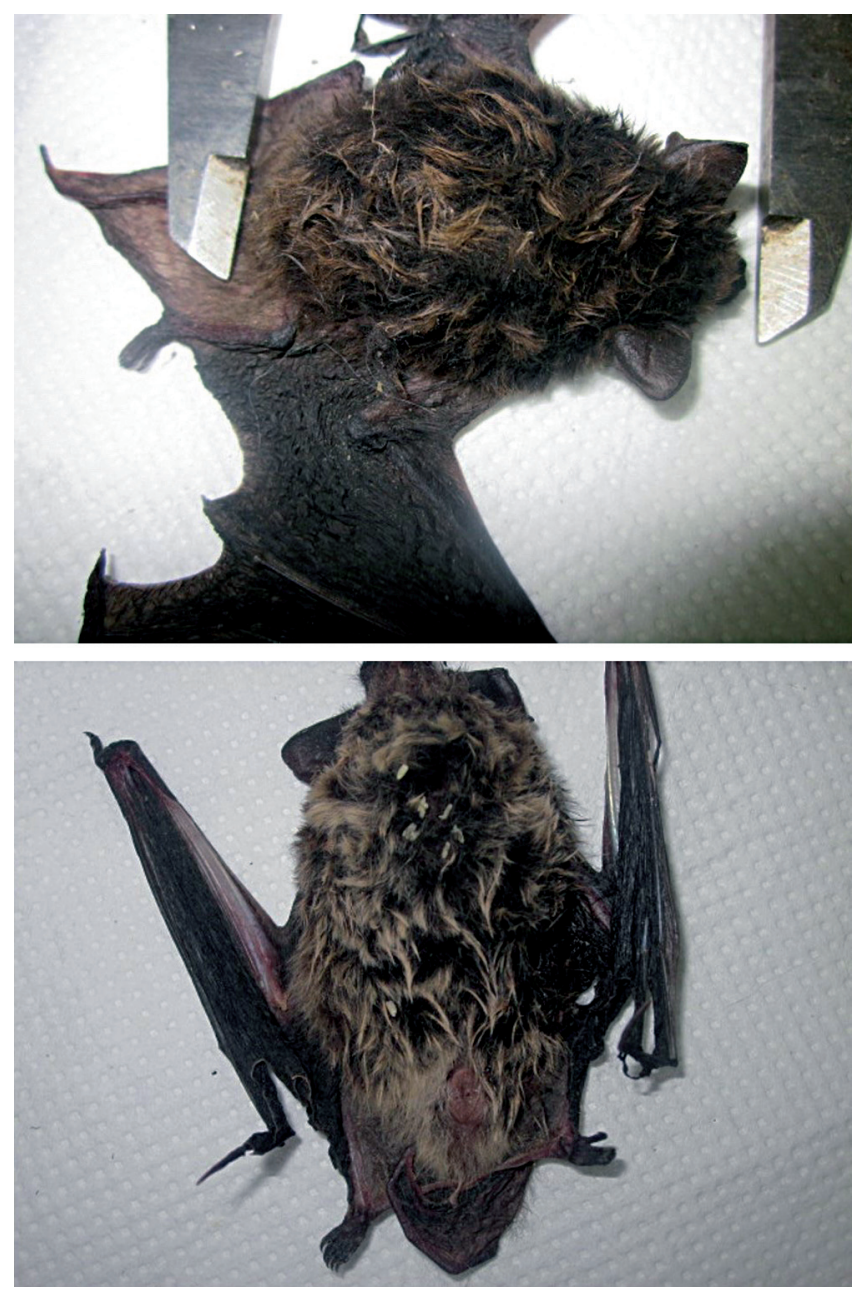

Fig. 4 - One of the four Savi's pipistrelles killed by RNPs in Reggio Emilia. / Uno dei quattro pipistrelli di Savi uccisi da parrocchetti dal collare a Reggio Emilia. 
the shoulders: Ancillotto et al., 2015; Postigo, 2016) have been recorded in Reggio Emilia frequently. Both the AP and RNP populations are growing, suggesting that further population increases should be expected in the next years (cf. Mori et al., 2020). Apart from AP and RNP, also the monk parakeet Myiopsitta monachus has been recorded as a breeding species in Reggio Emilia with 6-7 pairs up to 2017; then the species went extinct for unknown causes, both in Reggio Emilia and in the rest of Emilia Romagna region.

Mentil et al. (2018) showed that damage to orchards by the generalist RNPs may occur where population densities are higher (e.g. in Rome). In our work, we showed that flocks of parakeets may be responsible for a substantial consumption of persimmons, and that the population increase that we are witnessing could potentially result in an increased crop damage, particularly in the outskirts and in periurban areas. RNPs are reported as crop raiders also in their native ranges (Ahmad, 2011; Ahmad et al., 2012); therefore, the same impact can be expected in Southern Europe, especially on sunflowers and almond, olive and orange trees or other Mediterranean crops grown in suburban areas. Parakeets belonging to the genus Psittacula nest preferentially in tree cavities, which availability may be poor in urban areas. Instead, these birds may also use artificial cavities, such as those occurring on buildings (e.g. Grandi et al., 2018). Parakeets are early breeders: for this reason, they occupy cavities before native species (Pithon \& Dytham, 1999) and supplant those using these habitats for wintering, such as bats (Menchetti et al., 2014; Hernández-Brito et al., 2018). Hernández-Brito et al. (2014) showed that, in a similar habitat in Spain, RNPs may outcompete also a number of native birds, including some species of conservation concern. In our study area, four Savi's pipistrelles were driven away from their wintering cavities and killed by RNPs. When bats are active (during the warmer months), interaction with alien parakeets may be limited to bat displacement from roosts, but in cold months, when bats are torpid and not promptly reactive, the risk is even greater (Menchetti et al., 2014). Although we have no clear evidence of bats as a regular prey item, three bat carcasses were found partially consumed under nesting sites of the RNP where a killing of Savi's pipistrelle by RNPs was also observed.

Monitoring of new invasions is a basic tool to prevent potential damages by alien species and to trigger management interventions (Vall-1losera et al., 2017; Saavedra \& Medina, 2020). A new assessment of the European populations of both parakeet species should be carried out after five years from the previous one (Ancillotto et al., 2015; Pârâu et al., 2016), and should be forerun by the development of a citizen-science web-based project and scientific monitoring to investigate the status of the established populations (Chessa, 2020). The consumption of persimmons in urban areas suggests that RNP may also exert damages on orchards located in Reggio Emilia outskirts. Accordingly, given the scarcity of potential predators in the study area (e.g. see Menchetti \& Mori, 2014), the most likely population increase may bring RNPs to invade also suburban areas, where orchards are present together with a rich native species community, which may be outcom- peted by RNPs. Moreover, a strong impact by expanding populations of invasive RNPs on native European bats may occur through cavity displacement and direct killing events. Declines of bat populations and consequent disruption of their complex social behaviour may affect adversely their conservation status. With the exception of the still ongoing case recorded in Spain (Hernández-Brito et al., 2018), all recorded events including those of this study were documented at the onset of the invasion process by parrots, i.e. when cavities hosting bats started to be used by this bird species (Mori \& Menchetti, 2021). Predictions of range expansion, as well as prevention, early detection and early management of new invasions before establishment and spread (taking also into account human attitudes: Crowley et al., 2019; Luna et al., 2019) are thus paramount to preserve crops, native birds and urban bat colonies in European urban centres.

\section{Acknowledgements}

Authors would like to thank Stefano Manfredini, Elisabetta Mari, Marco Leporatti, Mattia Menchetti and Chiara Chessa for help in data collection, for information and for technical support. Two anonymous reviewers kindly took the time to improve the quality of our manuscript with their comments.

\section{REFERENCES}

Abed S. A., Salim M. A. \& Alsaffah S. M., 2020 - First record of Alexandrine parakeet Psittacula eupatria (Psittaculidae, Psittaciformes) (Linnaeus 1766) in Iraq. Indian Journal of Ecology, 47: 887-888.

Ahmad S., 2011 - Roost composition and damage assessment of roseringed parakeet (Psittacula krameri) on maize and sunflower in agro-ecosystem of central Punjab, Pakistan. International Journal of Agriculture and Biology, 13 (5): 731-736.

Ahmad S., Khan H. A. \& Javed M., 2012 - An estimation of rose-ringed parakeet (Psittacula krameri) depredations on citrus, guava and mango in orchard fruit farm. International Journal of Agriculture \& Biology, 14: 149-152.

Angelici F. M. \& Fiorillo A., 2015 - Repeated sightings of Alexandrine parakeet Psittacula eupatria in Rome (Central Italy) and its likely acclimatization. Rivista Italiana di Ornitologia, 85: 33-35.

Ancillotto L., Strubbe D., Menchetti M. \& Mori E., 2015 - An overlooked invader? Ecological niche, invasion success and range dynamics of the Alexandrine parakeet in the invaded range. Biological Invasions, 18: 583-595.

Bax N., Williamson A., Aguero M., Gonzalez E. \& Geeves W., 2003 Marine invasive alien species: a threat to global biodiversity. Marine Policy, 27: 313-323.

Borray-Escalante N. A., Mazzoni D., Ortega-Segalerva A., Arroyo L., Morera-Pujol J., González-Solís J. \& Senar J. C., 2020 - Diet assessments as a tool to control invasive species: comparison between Monk and Rose-ringed parakeets with stable isotopes. Journal of Urban Ecology, 6 (1): 1-8. < doi: 10.1093/jue/juaa005>

Casagrande D. \& Beissinger S. R., 1997 - Evaluation of four methods for estimating parrot population size. Condor, 99: 445-457.

Chessa C., 2020 - Parrocchetto dal collare e parrocchetto monaco in Italia: aggiornamento dello stato attuale delle popolazioni. BSc Dissertation in Scienze Naturali, Università degli Studi di Roma "La Sapienza", Roma, Italy.

Clavero M., Brotons L., Pons P. \& Sol D., 2009 - Prominent role of invasive species in avian biodiversity loss. Biological Conservation, 142: 2043-2049.

Clergeau P. \& Vergnes A., 2011 - Bird feeders may sustain feral Roseringed parakeets Psittacula krameri in temperate Europe. Wildlife Biology, 17: 248-252. 
Colautti R. I. \& MacIsaac H. J., 2004 - A neutral terminology to define 'invasive' species. Diversity and Distributions, 10: 135-141.

Crowley S. L., Hinchliffe S. \& McDonald R. A., 2019 - The parakeet protectors: understanding opposition to introduced species management. Journal of Environmental Management, 229: 120-132.

Dean W. R. J., 2000 - Alien birds in southern Africa: what factors determine success? South African Journal of Science, 96: 9-14.

Dodaro G. \& Battisti C., 2014 - Rose-ringed parakeet (Psittacula krameri) and starling (Sturnus vulgaris) syntopics in a Mediterranean urban park: evidence for competition in nest-site selection? Belgian Journal of Zoology, 144: 5-14.

Duncan R. P., Blackburn T. M. \& Sol D., 2003 - The ecology of bird introductions. Annual Review of Ecology, Evolution and Systematics, 34: 71-98.

Evans K. L., Chamberlain D. E., Hatchwell B. J., Gregory R. D. \& Gaston K. J., 2011 - What makes an urban bird? Global Change Biology, 17: 32-44.

Genovesi P. \& Shine C., 2004 - European strategy on invasive alien species: Convention on the Conservation of European Wildlife and Habitats (Bern Convention) (No. 18-137). Council of Europe, Strasbourg.

Grandi G., Menchetti M. \& Mori E., 2018 - Vertical segregation by ring-necked parakeets Psittacula krameri in northern Italy. Urban Ecosystems, 21: 1011-1017.

Haarsma A. J. \& Van der Graaf C., 2013 - Halsbandparkieten een bedreiging voor Rosse vleermuizen. De Levende Natuur, 114: 10-13.

Hernández-Brito D., Carrete M., Popa-Lisseanu A. G., Ibáñez C. \& Tella J. L., 2014 - Crowding in the city: losing and winning competitors of an invasive bird. PloS One, 9 (6), e100593.

Hernández-Brito D., Carrete M., Ibáñez C., Juste J. \& Tella J. L., 2018 - Nest-site competition and killing by invasive parakeets cause the decline of a threatened bat population. Royal Society Open Science, 5 (5): 172477.

Juniper T. \& Parr M., 1998 - Parrots: a guide to parrots of the world. Yale University Press, New Haven, Connecticut, USA.

Kark S., Iwaniuk A., Schalimtzek A. \& Banker E., 2007 - Living in the city: can anyone become an 'urban exploiter'? Journal of Biogeography, 34: 638-651.

Khaleghizadeh A. \& Sehhatisabet M. E., 2006 - Temporal variation in the numbers of the Alexandrine Parakeet, Psittacula eupatria, in Tehran, Iran. Zoology in the Middle East, 39: 107-108.

Krause T., 2004 - F1-und F2-Hybriden zwischen Alexandersittich Psittacula eupatria und Halsbandsittich P. krameri im Volksgarten in Dusseldorf. Charadrius, 40: 7-12.

Le Louarn M., Clergeau P., Briche E. \& Deschamps-Cottin M., 2017 "Kill Two birds with one stone": Urban tree species classification using bi-temporal Pléiades images to study nesting preferences of an invasive bird. Remote Sensing, 9 (9), 916. <https://doi. org/10.3390/rs9090916>

Le Louarn M., Couillens B., Deschamps-Cottin M. \& Clergeau P., 2016Interference competition between an invasive parakeet and native bird species at feeding sites. Journal of Ethology, 34: 291-298.

Lockwood J. L., Cassey P. \& Blackburn T. M., 2009 - The more you introduce the more you get: the role of colonization pressure and propagule pressure in invasion ecology. Diversity and Distributions, 15: 904-910.

Luna Á., Monteiro M., Asensio-Cenzano E. \& Reino L., 2016 - Status of the rose-ringed parakeet Psittacula krameri in Lisbon, Portugal. Biologia, 71: 717-720.

Luna Á., Edelaar P. \& Shwartz A., 2019 - Assessment of social perception of an invasive parakeet using a novel visual survey method. Neobiota 46: 71-89.

Mack R. N., Simberloff D., Mark Lonsdale W., Evans H., Clout M. \& Bazzaz F. A., 2000 - Biotic invasions: causes, epidemiology, global consequences, and control. Ecological Applications, 10: 689-710.

Menchetti M. \& Mori E., 2014 - Worldwide impact of alien parrots (Aves Psittaciformes) on native biodiversity and environment: a review. Ethology Ecology \& Evolution, 26: 172-194.

Menchetti M., Scalera R. \& Mori E., 2014 - First record of a possibly overlooked impact by alien parrots on a bat (Nyctalus leisleri). Hystrix, Italian Journal of Mammalogy, 25: 61-62.
Mentil L., Battisti C. \& Carpaneto G. M., 2018 - The impact of Psittacula krameri (Scopoli, 1769) on orchards: first quantitative evidence for Southern Europe. Belgian Journal of Zoology, 148: 129-134.

Møller A. P., 2009 - Successful city dwellers: a comparative study of the ecological characteristics of urban birds in the Western Palearctic. Oecologia, 159: 849-858.

Mori E. \& Menchetti M., 2021 - The Ecological Impacts of introduced parrots. In: Naturalized parrots of the world. Distribution, ecology, and impacts of the world's most colorful colonizers. Pruett-Jones S. (ed.). Princeton University Press, New Jersey, USA: 87-101.

Mori E., Sala J. P., Fattorini N., Menchetti M., Montalvo T. \& Senar J. C., 2019 - Ectoparasite sharing among native and invasive birds in a metropolitan area. Parasitology Research, 118: 399-409.

Mori E., Onorati G. \& Giuntini S., 2020 - Loud callings limit human tolerance towards invasive parakeets in urban areas. Urban Ecosystems, 23: 755-760.

Pârâu L. G., Strubbe D., Mori E., Menchetti M., Ancillotto L., van Kleunen A., White R. L., Hernàndez-Brito D., Le Louarn M., Clergeau P., Albayrak T., Franz D., Braun M. P., Schroeder J. \& Wink M., 2016 - Rose-ringed parakeet Psittacula krameri populations and numbers in Europe: a complete overview. The Open Ornithology Journal, 9: 1-13.

Pithon J. A. \& Dytham C., 1999 - Breeding performance of Ringnecked Parakeets Psittacula krameri in small introduced populations in southeast England. Bird Study, 46: 342-347.

Postigo J. L., 2016 - New records of invasive parakeet hybrids in Spain. A great opportunity to apply the rapid response mechanism. European Journal of Ecology, 2: 19-22.

Pyšek P., Hulme P. E., Simberloff D., Bacher S., Blackburn T. M., Carlton J. T., Dawson W., Essl F., Foxcroft L. C., Genovesi P., Jeschke J. M., Kühn I., Liebhold A. M., Mandrak N. E., Meyerson L. A., Pauchard A., Pergl J., Roy H. E., Seebens H., van Kleunen M., Vilà M., Wingfield M. J. \& Richardson D. M., 2020 - Scientists' warning on invasive alien species. Biological Reviews, 95: 1511-1534.

Saavedra S. \& Medina F. M., 2020 - Control of invasive ring-necked parakeet (Psittacula krameri) in an island Biosphere Reserve (La Palma, Canary Islands): combining methods and social engagement. Biological Invasions, 22: 3653-3667.

Şahın D. \& Arslangündoğdu Z., 2019 - Breeding status and nest characteristics of Rose-ringed (Psittacula krameri) and Alexandrine parakeets (Psittacula eupatria) in Istanbul's city parks. Applied Ecology and Environmental Research, 17: 2461-2471.

Seress G. \& Liker A., 2015 - Habitat urbanization and its effects on birds. Acta Zoologica Academiae Scientiarum Hungaricae, 61: 373-408.

Sol D., Bartomeus I. \& Griffin A. S., 2012 - The paradox of invasion in birds: competitive superiority or ecological opportunism? Oecologia, 169: 553-564.

Sourav M. S. H., Thompson P. M. \& Biswas K. F., 2018 - Population and behavioural ecology of Alexandrine Parakeet Psittacula eupatria in Dhaka city, Bangladesh. Forktail, 34: 22-28.

Vall-1losera M., Woolnough A. P., Anderson D. \& Cassey P., 2017 Improved surveillance for early detection of a potential invasive species: the alien Rose-ringed parakeet Psittacula krameri in Australia. Biological Invasions, 19: 1273-1284.

White R., Strubbe D., Dallimer M., Davies Z. G., Davis A. J. S., Edelaar P., Groombridge J., Jackson H. A., Menchetti M., Mori E., Nikolov B. P., Pârâu L. G., Pečnikar Ž. F., Pett T. J., Reino L., Tollington S., Turbè A. \& Shwartz A., 2019 - Assessing the ecological and societal impacts of alien parrots in Europe using a transparent and inclusive evidence-mapping scheme. Neobiota, 48: 45-69. 